\title{
First record of a wolf spider, Draposa lyrivulva (Bösenberg \& Strand 1906) (Araneae: Lycosidae), from the Maldivian Islands, Indian Ocean
}

\author{
Sebastian Steibl ${ }^{1 *}$, Francesco Ballarin ${ }^{2}$, Anton A. Nadolny ${ }^{3} \&$ Christian Laforsch ${ }^{1}$ \\ ${ }^{1}$ Department of Animal Ecology and BayCEER, University of Bayreuth, Universitaetsstr. 30, D-95440 Bayreuth, Germany \\ ${ }^{2}$ Systematic Zoology Laboratory, Department of Biological Sciences, Tokyo Metropolitan University, 1-1 Minami-Osawa, $192-0397$ \\ Tokyo, Japan \\ ${ }^{3}$ A. O. Kovalevsky Institute of Biology of the Southern Seas of RAS, Nakhimov Avenue 2, Sevastopol 299011 \\ E-mail: sebastian.steibl@uni-bayreuth.de, *Corresponding author
}

\begin{abstract}
We report the first record of the wolf spider Draposa lyrivulva (Bösenberg \& Strand 1906) outside its known distribution in Pakistan, India and the island of Sri Lanka on the remote tropical islands of the Maldives. It is the first species report of any Lycosidae from these islands. As this remote archipelago in the Indian Ocean lies about $500 \mathrm{~km}$ off the Indian subcontinent and comprises more than 1100 islands, the finding of D. lyrivulva as a common species there suggests that this spider could have colonized the islands either via aerial dispersal, rafting or has been introduced by humans.
\end{abstract}

Key words - coralline, Maldives, spider fauna, wolf spider

\section{Introduction}

Wolf spiders (Lycosidae Sundevall 1833) are a large family of spiders comprising more than 2400 species (World Spider Catalog 2020). They are abundant and usually related to grassland and other open habitats, where they are polyphagous predators on a multitude of prey species (Oelbermann $\&$ Scheu 2002; Jocqué \& Alderweireldt 2005). Due to the ability of many Lycosidae species to aerial dispersal, they have colonized most temperate to tropical habitats worldwide (Richter 1970; Piacentini \& Ramírez 2019).

Besides their continental distribution, different Lycosidae species have therefore already been reported from several remote oceanic islands, e.g. Micronesia or Marshall Islands in the Pacific Ocean (Framenau, Betty \& Beatty 2009). However, in one major region within the Indian Ocean, the Maldivian archipelago, there are so far no confirmed species reports of Lycosidae. The Maldivian archipelago lies south of the Indian subcontinent and Sri Lanka in the Indian Ocean, spanning from latitudes of $8^{\circ}$ North over the equator to $1^{\circ}$ South. The Maldives comprise more than 1100 small coralline islands that are arranged in 26 atolls. These islands are not larger than one or two square kilometers (most even considerably smaller than one square kilometer) but because of their tropical environment, they support a variety of terrestrial invertebrate taxa (Hogarth et al. 1998; Sunil 2012; Taiti 2014).
Due to the scattered distribution and overall geography of the islands, comprehensive studies investigating the fauna on all 26 atolls (or the 1192 islands) are almost impossible to realize and therefore new species for this region are still reported regularly. The spider fauna of the Maldives has been reviewed in 2012 with 57 species from 35 genera and 17 families reported (Sunil 2012). Nevertheless, no Lycosidae species have been recorded so far from these islands, although Sunil (2012) reported the finding of two unidentified specimens termed Pardosa sp. 1 and 2.

Examining spider samples collected on numerous Maldivian islands, we noticed the presence of an unrecorded species belonging to the family Lycosidae. Here, we report for the first time the occurrence of the wolf spider Draposa lyrivulva (Bösenberg \& Strand 1906) on the Maldives. This species belongs to the recently established genus Draposa Kronestedt 2010 and it has thus far only been recorded from continental India and Pakistan and the adjacent island of Sri Lanka (Kronestedt 2010).

\section{Materials and Methods}

The sampling was carried out in the Lhaviyani (Faadhippolhu) and North Male' (Uthuruburi) Atoll in the central Maldives in January 2020 (Fig. 1). 15 islands in the Lhaviyani atoll and one island in the North Male' Atoll were investigated. On 15 out of the 16 investigated islands, specimens were found and collected. The collected spiders were 


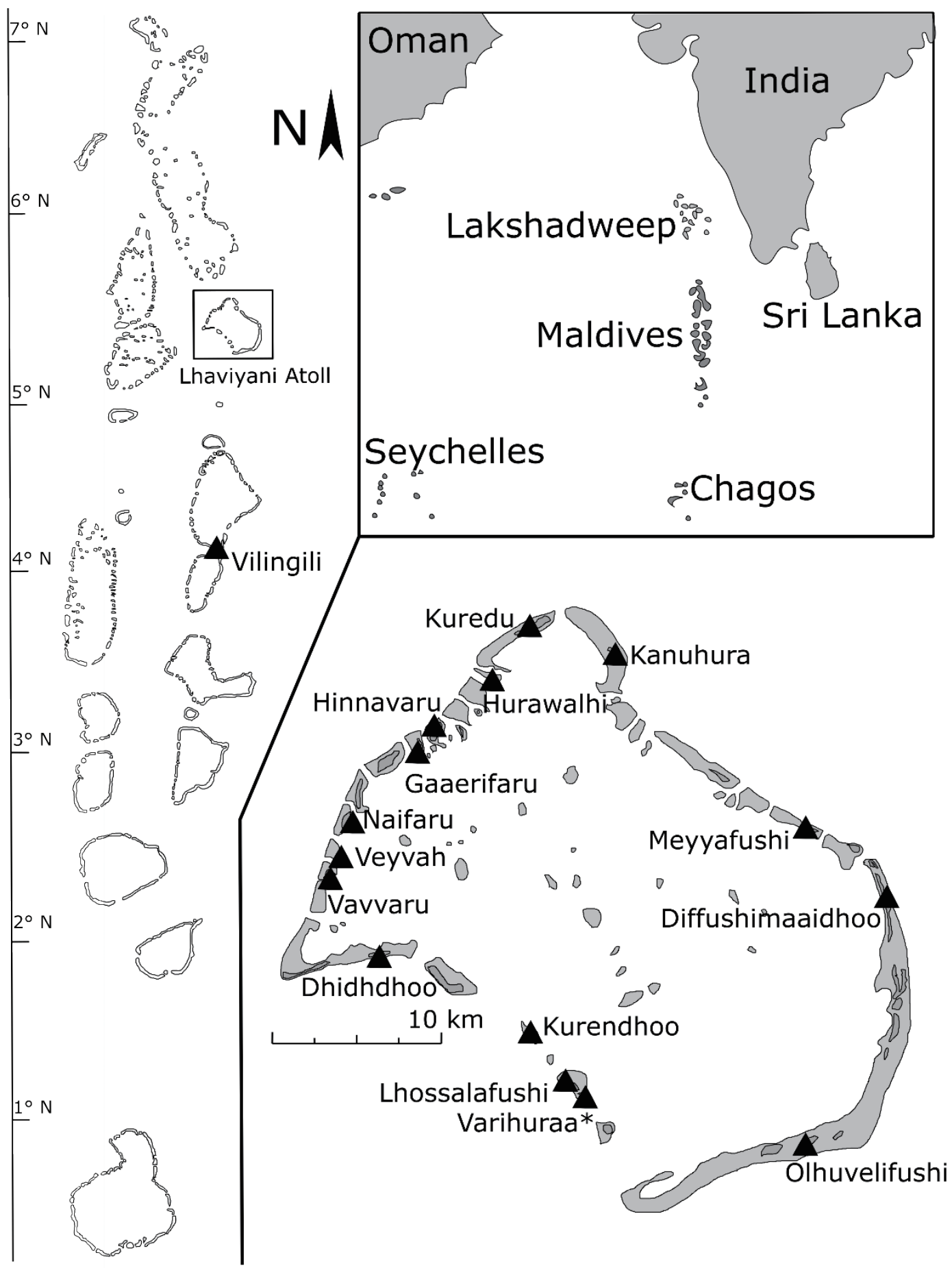

Fig. 1. Map of the study area (top right, location of Maldives within Indian Ocean; left, location of Lhaviyani Atoll within Republic of Maldives; bottom right, location of investigated islands within Lhaviyani Atoll), black triangles indicate islands that were investigated. Specimens of Draposa lyrivulva were found on all investigated islands, except for Varihuraa (indicated by asterisk). 

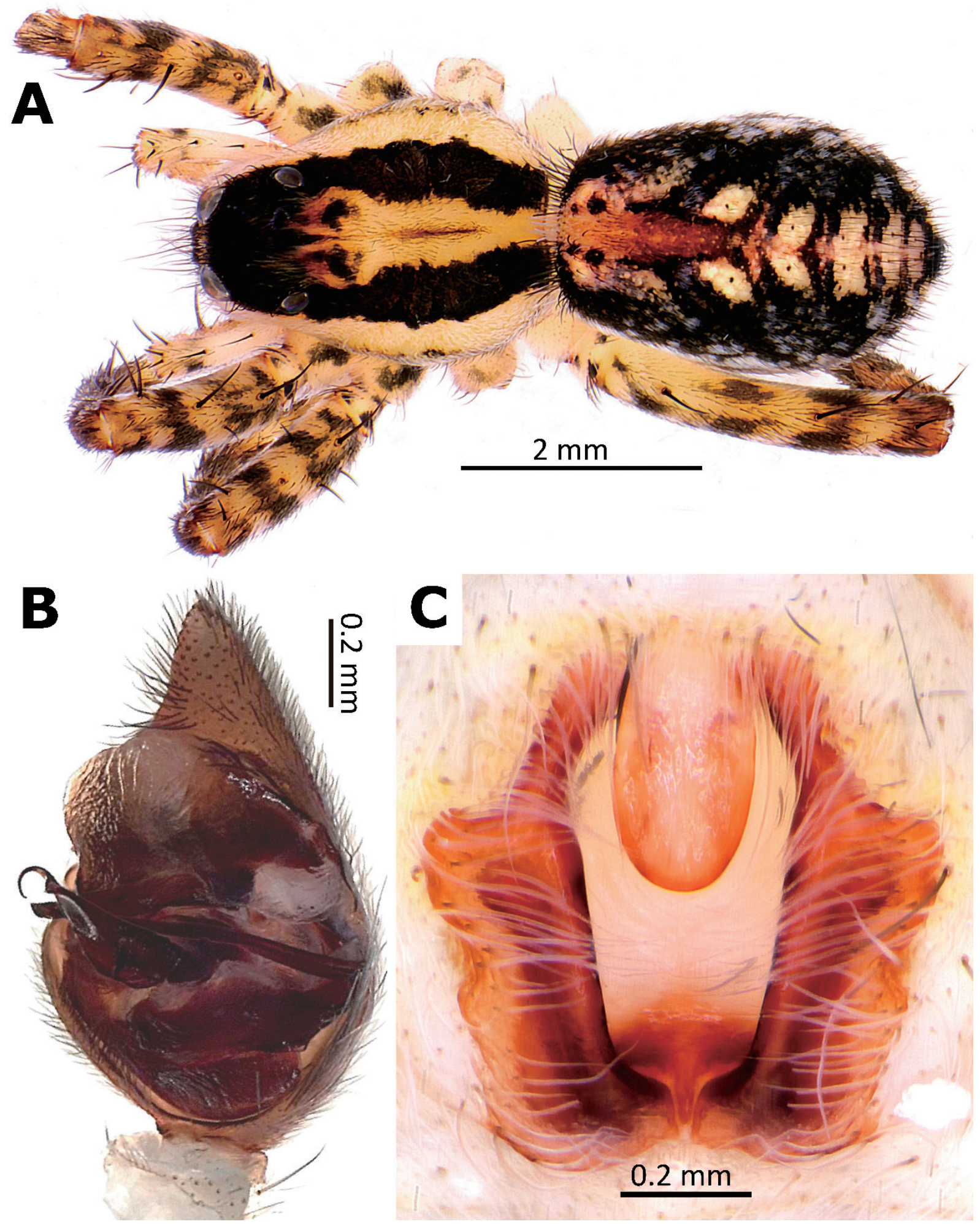

Fig. 2. Details of Draposa lyrivulva from Gaaerifaru Island, Maldives: A, female habitus; B, male palp, ventral view; C, epigyne, ventral view. 
fixated in $98 \%$ ethanol and stored at $8^{\circ} \mathrm{C}$ in a freezer at the Department of Animal Ecology, University of Bayreuth, Germany (UBT). Morphology was examined using a Leica DVM6 (Leica Camera AG, Wetzlar, Germany) and a Nikon SMZ1270 stereomicroscope (Nikon Corp., Tokyo, Japan) and photographed with a Canon EOS Kiss x8i (Canon AG, Tokyo, Japan) and Leica Camera AG digital cameras attachments. Resulting photos were combined using the image stacking software Helicon Focus 6.7.1. Morphology of male palp and epigyne were compared to drawings from the recent revision of the genus Draposa (Kronestedt 2010). The nomenclature follows the World Spider Catalog (2020).

\section{Results and Discussion \\ Family Lycosidae Sundevall 1833 \\ Genus Draposa Kronestedt 2010 \\ Draposa lyrivulva (Bösenberg \& Strand 1906)}

Lycosa lyrivulva Bösenberg \& Strand 1906: 326 (ㅇ)

Pardosa leucopalpis Tikader \& Malhotra 1980: 349, figs 203-206 (ô?).

P. lyrivulva Tanaka 1993: 176, fig 5 (우).

Draposa lyrivulva Kronestedt 2010: 39, fig 5-6, 15-18, 24, 30, 33-41 (ぷ).

For the complete list of references see the World Spider Catalog 2020

\section{Material examined:}

Maldives, Lhaviyani (Faadhippolhu) Atoll: 1 ก, 1 , Naifaru Island, reclaimed area (5.44066, 73.363055), 6.I.2020; $1 \hat{\sigma}$, Veyvah island, transition zone beach-inland (5.42463, 73.36138), 9.I.2020; 2 q, Vavvaru island transition zone beach-inland (5.41690, 73.35437), 10.I.2020; 1 q, Hinnava$\mathrm{ru}$ island, reclaimed area (5.49186, 73.41000), 11.I.2020; 4 ô, 1 q, Gaaerifaru island, transition zone between beach and inland (5.48627, 73.403055), 12.I.2020; 1 , Kuredu island, tourist area $(5.54719,73.46416), 13.1 .2020 ; 1$ ㅇ, Kanuhura island, tourist area $(5.53516,73.50472), 14.1 .2020 ; 2$ ㅇ, Kurendhoo island, reclaimed area $(5.33313,73.46194)$, 15.I.2020; 3 , Dhidhdhoo island, transition zone beach-inland (5.37661, 73.38222), 16.I.2020; 4 \%, Olhuvelifushi island, harbor area $(5.27711,73.60500), 19.1 .2020 ; 3$ ㅇ, Lhossalafushi island, transition zone beach-inland (5.30613, 73.48750), 26.I.2020; 2 ㅇ, Diffushimaaidhoo and Meyyafushi island, transition zone beach-inland (5.41138, 73.64416), 27.I.2020; 1 9, Hurawalhí island, tourist area (5.52191, 73.44138), 28.I.2020; 1 q, North Male’ Atoll: Vilingili island, reclaimed area $(4.17197,73.48722)$, 29.I.2020, all specimen collected by S. Steibl (UBT)

Description: Habitus and copulatory organs as in Fig. 2A-C. For a detailed description of D. lyrivulva and the genus Draposa, refer to Bösenberg \& Strand (1906) and Kronestedt (2010).

Ecology: The specimens were collected on pristine uninhabited islands, islands used for touristic purposes, and islands inhabited by the local Maldivian population. On all islands, the specimens were found in the transition zone between beach and inland, where the first pioneering plants (mainly Cyperus dubius, Launaea sarmentosa, Dactyloctenium spp., Cassytha filiformis) occurred and in the reclaimed grass areas on the inhabited islands.

Remarks on distribution: $D$. lyrivulva has been described for the first time by Bösenberg \& Strand in 1906 based on a single female from Saga Prefecture in Kyushu Island, Western Japan. Since then, this species has never been found in the type locality or in any other parts of Japan (Tanaka 1993). It is thus considered probably introduced in Japan or mislabeled (Kronestedt 2010). Other records of $D$. lyrivulva were reported so far only from continental India and Pakistan and adjacent Sri Lanka (World Spider Catalog 2020). Our findings extend the area of distribution of this species approximately $500 \mathrm{~km}$ to the South. Our data is the first confirmed report of a wolf spider species from the Maldives. In its extensive study on the Maldivian spider fauna, Sunil (2012) previously reported the finding of an unidentified Lycosidae (Pardosa sp.). Although unconfirmed, it is likely that his records refer to $D$. lyrivulva. The discovery of D. lyrivulva on several islands in the Maldivian archipelago shows that this species is widespread and a common resident on the islands off the Indian mainland in the Indian Ocean. As the genus Draposa is widespread in the Indomalayan region, it remains uncertain if this species colonized the Maldivian archipelago either naturally or artificially. We suggest that $D$. lyrivulva may have colonized the Maldivian archipelago either via aerial dispersal, rafting or it has been unintentionally introduced by human settlers

\section{Acknowledgments}

We thank the NGOs 'Naifaru Juvenile' and 'Atoll Marine Centre' for providing infrastructure and accommodation during the field stay. Financial support for Sebastian Steibl from the scholarship 'Studienstiftung des deutschen Volkes' is gratefully acknowledged. We thank Mechthild Kredler for their help in preparing the pedipalps of the collected specimens. We are equally grateful to the two anonymous reviewers for their comments which helped to improve the manuscript. The work of A. A. Nadolny was carried out within the framework of the State research assignment of IBSS (AAAA-A18-118020890074-2)

\section{References}

Bösenberg, W. \& Strand, E. 1906. Japanische Spinnen. Abhandlungen Hrsg. von der Senckenbergischen Naturforschenden Gesellschaft, 30: $93-422$.

Framenau, V. W., Berry, J. W., \& Beatty, J. A. 2009. Wolf spiders of the Pacific region: the genus Zoica (Araneae, Lycosidae). J Arachnol. 37: 225-231.

Jocqué, R., \& Alderweireldt, M. 2005. Lycosidae: the grassland spiders. Acta Zoologica Bulgarica, 1: 125-130.

Hogarth, P. J., Gherardi, F. \& McLaughlin, P. A. 1998. Hermit crabs (Crustacea Decapoda Anomura) of the Maldives with the description of a new species of Catapagurus A. Milne Edwards 1880. Trop. Zool., 11: 149-175.

Kronestedt, T. 2010. Draposa, a new wolf spider genus from South and Southeast Asia (Araneae: Lycosidae). Zootaxa, 54: 31-54.

Oelbermann, K., \& Scheu, S. 2002. Stable isotope enrichment $\left(\delta^{15} \mathrm{~N}\right.$ and $\delta^{13} \mathrm{C}$ ) in a generalist predator (Pardosa lugubris, Araneae: Lycosidae): effects of prey quality. Oecologia, 130: 337-344.

Piacentini, L. N., \& Ramírez, M. J. 2019. Hunting the wolf: a molecu- 
lar phylogeny of the wolf spiders (Araneae, Lycosidae). Mol. Phyl. Evol., 136: 227-240.

Richter, C. J. J. 1970. Aerial dispersal in relation to habitat in eight wolf spider species (Pardosa, Araneae, Lycosidae). Oecologia, 5: 200-214.

Sundevall, J. C. 1833. Svenska spindlarnes beskrifning. Fortsättning och slut. Kongl. Svenska Vet. Ak. Handl., 1832: 172-272.

Sunil, J. K. 2012. The spider fauna of Maldive islands in Indian Ocean (Araneae). Munis Entomol. Zool., 7: 424-431.

Taiti, S. 2014. The terrestrial Isopoda (Crustacea, Oniscidea) of the
Maldives. Trop. Zool., 27: 9-33.

Tanaka, H. 1993. Lycosid spiders of Japan XII. The genus Pardosa C. L. Koch - pullata-group and P. lyrivulva. Acta Arachnol., 42: $173-179$.

World Spider Catalog 2020. World Spider Catalog, Natural History Museum Bern, online at http://wsc.nmbe.ch, version 21.0, accessed on 01 June 2020.

Received July 6, 2020/ Accepted September 1, 2020 